\title{
Performa Reproduksi Sapi Perah di Sumatera Barat
}

\section{Reproduction Performance of Dairy Cows in West Sumatra}

\author{
Reswati, Jaswandi dan E. Nurdin \\ Fakultas Peternakan Universitas Andalas \\ Kampus Unand Limau Manis Padang 25163 \\ E-mail: reswatisyafri@yahoo.com \\ (Diterima: 03 Januari 2013 ; Disetujui: 13 Mei 2013)
}

\begin{abstract}
ABSTRAK
Penelitian bertujuan untuk mengetahui performa reproduksi sapi perah di Sumatera Barat. Metode yang dilakukan adalah survey terhadap 24 ekor sapi perah yang dikelola oleh perusahaan di Kabupaten 50 Kota dan 35 ekor sapi perah yang dikelola oleh peternakan rakyat di Kota Padang Panjang. Analisis data dengan deskriptif, serta dilakukan uji T dengan program SPSS versi 12. Hasil penelitian menunjukkan umur beranak pertama (Age at First Calving) sapi perah di Kabupaten 50 Kota dan Kota Padang Panjang masing-masing 31,63 $\pm 6,37$ bulan dan 30,17 $\pm 4,10$ bulan; masa kosong (Days Open) 260,63 $\pm 147,04$ hari dan 192,26 $\pm 114,04$ hari; sedangkan selang beranak (calving interval) 548,63 $\pm 168,30$ hari dan 477,26 $\pm 114,04$ hari. Performa reproduksi di kedua daerah ini belum baik karena melebihi jangka waktu optimal untuk ketiga variabel tersebut. Tidak ada perbedaan $(\mathrm{P}>0,05)$ antara penampilan reproduksi sapi perah di kedua daerah penelitian.

Kata kunci : sapi perah, performans reproduksi, umur beranak pertama, masa kosong, selang beranak
\end{abstract}

\section{ABSTRACT}

The objective of this research was to analyse reproduction performance of dairy cows in West Sumatra. A survey was carried out to 24 dairy cows at an enterprise in 50 Kota District and 35 dairy cows owned by small-scale dairy farmers in Padang Panjang. Collected data were analyzed by descriptive approach as well as T test using SPSS version 12. The results showed that cow average age at the first calving at both locations were 31,63 $\pm 6,37$ months and 30,17 $\pm 4,10$ months respectively; the average of days open was 260,63 $\pm 147,04$ days and 192,26 $\pm 114,04$ days respectively; and the average of calving interval was 548,63 $\pm 168,3$ days and 477,26 $\pm 114,04$ dayas respectively. Thus, reproduction performance had been categorized as not good enough due to go beyond the optimal standard duration based on those three indicators. There was not a significant $(P>0.05)$ reproduction performace of dairy cows between both farms location.

Keywords : dairy cow, reproduction performance, age at first calving, days open and calving interval

\section{PENDAHULUAN}

Susu sapi merupakan salah satu sumber protein hewani yang mengandung nilai nutrisi tinggi sebagai penyumbang dalam pemenuhan Angka Kecukupan Gizi (AKG) masyarakat di Indonesia. Kebutuhan akan susu sapi dan produknya terus meningkat dari tahun ke tahun sebagai akibat dari bertambahnya jumlah penduduk, pendapatan dan tingkat kesadaran masyarakat Indonesia. Namun kebutuhan tersebut tidak dapat dipenuhi oleh produksi susu dalam negeri sehingga harus dilakukan impor berupa susu segar maupun produk olahan susu. Dari data yang tersedia (Ditjen Peternakan dan Kesehatan Hewan, 2013) terlihat bahwa terjadi peningkatan impor susu dan produknya mulai tahun 2010, 2011 dan 2012 dengan jumlah masing-masing sebanyak 231.396 ton, 247.495 ton dan 386.116 ton. Impor ini akan terus meningkat jika produksi susu dalam negeri tidak ditingkatkan. 
Sumatera Barat merupakan salah satu provinsi sentra pengembangan sapi perah dan sebagai daerah penyumbang dalam pemenuhan kebutuhan susu nasional, namun pada tahun 2012 tercatat populasi sapi perahnya hanya $0,11 \%$ dari populasi sapi perah di Indonesia (Ditjen Peternakan dan Kesehatan Hewan, 2013). Populasi sapi perah terbesar $(43,44 \%)$ terdapat di Kota Padang Panjang sementara sisanya tersebar di beberapa daerah lain seperti Kabupaten 50 Kota, Solok, Tanah Datar, Agam, Kota Padang, Payakumbuh, Sawahlunto dan Bukittinggi (Dinas Peternakan Provinsi Sumbar, 2012). Perkembangan usaha peternakan sapi perah di Sumatera Barat kurang menggembirakan terlihat dari partumbuhan negatif populasi sapi perah mulai tahun 2009 sebanyak 826 ekor dan pada tahun 2012 menjadi 642 ekor (Dinas Peternakan Provinsi Sumbar, 2012). Dari data tersebut terlihat bahwa terdapat permasalahan dalam pertumbuhan populasinya, sehingga perkembangan usaha peternakan sapi perah di Sumatera Barat tidak sesuai dengan yang diharapkan. Tidak mustahil populasi ini akan terus menurun jika tidak segera dicari akar permasalahan dan solusi pemecahan masalahnya sehingga pertumbuhan populasi sapi perah di Sumatera Barat dapat ditingkatkan dan memberikan kontribusi yang lebih besar dalam memenuhi kebutuhan susu secara nasional.

Produksi susu dan reproduksi merupakan dua hal yang tidak dapat dipisahkan karena keduanya merupakan faktor utama yang mempengaruhi efisiensi dan keuntungan usaha peternakan sapi perah (Bujko et al., 2012). Seekor sapi perah akan menghasilkan susu setelah melahirkan dan akan berlanjut jika proses reproduksi terus berlangsung. Jika proses reproduksi berjalan normal maka setiap tahun seekor sapi perah dapat menghasilkan satu ekor anak dengan produksi susu normal sesuai dengan potensi genetik masing-masing individu, sehingga pertumbuhan populasi dapat mencapai tingkat yang optimal. Namun bila siklus reproduksi tidak berjalan secara normal, maka selang beranak (calving internal) menjadi panjang yang akan menyebabkan partumbuhan populasi menjadi lambat.
Salah satu upaya yang perlu dilakukan untuk mengatasi hal tersebut adalah dengan melakukan perbaikan manajemen pemeliharaan, salah satunya adalah manajemen reproduksi.

Manajemen reproduksi merupakan bagian yang amat penting dalam suatu usaha peternakan karena daya reproduksi kelompok ternak yang tinggi disertai dengan manajemen reproduksi yang baik akan menghasilkan efisiensi yang tinggi dengan produktivitas ternak yang tinggi pula. Performans reproduksi yang sering menjadi indikator dalam penilaian efisiensi reproduksi adalah umur beranak pertama (age at first calving), waktu kosong (days open) dan jarak beranak (calving interal), karena ketiga faktor ini berpengaruh terhadap produksi susu.

Umur beranak pertama merupakan faktor yang penting dalam pemeliharaan sapi da$\mathrm{ra}$, semakin lambat umur beranak pertama maka biaya pemeliharaan akan semakin tinggi. Berdasarkan perbandingan produksi susu dan biaya pemeliharaan, sapi perah yang beranak pertama pada umur 23-24 bulan akan lebih menguntungkan bagi usaha peternakan sapi perah (Pirlo et al., 2000). Biaya pemeliharaan akan berkurang $18 \%$ bila umur beranak pertama berkurang dari 25 bulan menjadi 21 bulan (Tozer and Heinrichs, 2001).

Jarak beranak (calving internal) merupakan jarak antara satu kelahiran dengan kelahiran berikutnya. Melahirkan kembali disamping menghasilkan pedet berarti juga kembali menghasilkan susu yang akan memberikan keuntungan kepada peternak. Jarak beranak dipengaruhi oleh lamanya masa kosong (days open). Semakin panjang masa kosong maka semakin panjang jarak beranak, berarti menunda kesempatan peternak untuk mendapatkan keuntungan yang berasal dari produksi susu dan anak. Panjangnya jarak beranak ini akan menyebabkan lambatnya pertumbuhan populasi sapi perah di Indonesia.

Dalam upaya peningkatan populasi sapi perah di Sumatera Barat maka dilakukan penelitian yang bertujuan untuk mendapatkan gambaran tentang performans reproduksi sapi perah yang meliputi umur beranak bertama (age at first calving), masa kosong (days 
open) dan selang beranak (calving interval. Dari hasil penelitian ini diharapkan dapat ditemukan permasalahan yang dihadapi dalam pengembangan populasi usaha sapi perah di Sumatera Barat dilihat dari aspek performa reproduksinya.

\section{METODE}

Penelitian ini dilaksanakan pada dua daerah sentra sapi perah di Sumatera Barat yaitu Kabupaten 50 Kota dan Kota Padang Panjang. Usaha peternakan sapi perah yang dipilih sebagai responden adalah PT. Situjuh Organik Madani yang terletak di Jorong Subarang Tabek Nagari Situjuah Banda Dalam Kecamatan Situjuah Limo Nagari Kabupaten 50 Kota dan usaha peternakan rakyat di Kota Padang Panjang.

Penelitian dilakukan dengan menggunakan metode survey dan pengamatan langsung ke lokasi usaha peternakan. Pemilihan sampel dilakukan dengan teknik purposive sampling dengan memilih sapi yang telah memasuki masa laktasi satu sampai dengan empat. Data yang dikumpulkan adalah data primer yang berasal dari catatan reproduksi sapi perah sebanyak 24 ekor di Kabupaten 50 Kota dan 35 ekor di Kota Padang Panjang. Kemudian dilakukan wawancara dengan peternak menggunakan daftar pertanyaan (kuisioner) serta pengamatan langsung di lapangan. Sedangkan data sekunder diperoleh dari instansi terkait dan studi literatur.

Variabel performa reproduksi yang diamati adalah : 1) Umur beranak pertama (age at first calving) yaitu umur saat sapi pertama kali beranak yang dihitung dalam bulan, 2) Masa kosong (Days Open) yang dihitung mulai saat sapi melahirkan sampai terjadinya bunting kembali dan 3) Selang beranak (calving interval) yaitu jarak kelahiran antara dua anak yang dihitung dalam hari. Data yang diperoleh dianalisa dengan menggunakan analisa deskriptif yaitu dalam bentuk rataan dan standar deviasi. Untuk melihat perbandingan antara performans reproduksi sapi perah yang ada di Kabupaten 50 Kota dan Kota Padang Panjang dilakukan Uji T dengan mempergunakan program komputer SPSS
(Statistical Product and Service Solution) versi 12.

\section{HASIL DAN PEMBAHASAN}

\section{Kondisi Umum}

Kabupaten 50 Kota merupakan salah satu kabupaten di Sumatera Barat dengan topografi daerah yang bervariasi antara datar, bergelombang dan berbukit-bukit dengan ketinggian 110 - 791 meter di atas permukaan laut. Usaha peternakan PT. Situjuh Organik Madani berada di kaki Gunung Sago sehingga berudara sejuk dengan suhu berkisar antara $17^{0}-23^{0}$ C (BPS Kabupaten 50 Kota, 2011) yang sangat mendukung untuk pemeliharaan sapi perah jenis Friesien Holstein (FH). Pada saat penelitian ini terdapat 56 ekor sapi yang terdiri dari 5 ekor sapi simmental dan 51 ekor sapi FH (24 ekor induk, 3 ekor jantan, 13 ekor dara dan 11 ekor anak jantan dan betina) dengan rataan produksi susu harian $10,15 \mathrm{~kg}$ per ekor.

Kota Padang Panjang adalah kota berhawa sejuk yang berada pada ketinggian 650850 meter di atas permukaan laut dengan suhu berkisar antara $18^{0}-25^{\circ} \mathrm{C}$ (BPS Kota Padang Panjang, 2011). Terdapat gunung aktif yaitu Gunung Merapi sehingga memiliki tanah subur dan memungkinkan tumbuhnya hijauan pakan ternak dengan baik, juga menunjang untuk pengembangbiakan sapi perah karena suhu udaranya yang sejuk. Karakteristik peternak sapi perah di Kota Padang Panjang dapat dilihat pada Tabel 1.

Usaha peternakan sapi perah di Kota Padang Panjang ini merupakan peternakan rakyat yang umumnya tergabung dalam kelompok tani. Peternak umumnya mendapat bantuan sapi jenis $\mathrm{FH}$ dari pemerintah dimulai sejak tahun 1981 sampai dengan sekarang. Rataan umur peternak 44,83 tahun dimana $38,89 \%$ diantaranya berumur 25-40 tahun dan 61,11\% berumur 41-60 tahun. Sebagian besar peternak $(77,77 \%)$ berpendidikan SLTA ke bawah sedangkan yang lainnya $(22,23 \%)$ berpendidikan diploma dan Sarjana. Tingkat pendidikan peternak di Kota Padang Panjang ini lebih tinggi dari peternak sapi perah di Kebon Pedes Kota Bogor yang berpendidikan sarjana 
Tabel 1. Karakteristik peternak dan usaha peternakan sapi perah di Kota Padang Panjang

\begin{tabular}{|c|c|c|c|}
\hline No. & Kriteria & Rataan & Persentase \\
\hline \multirow[t]{3}{*}{1} & Umur Peternak (tahun) & 44,83 & \\
\hline & a. $25-40$ tahun & & 38,89 \\
\hline & b. $41-60$ tahun & & 61,11 \\
\hline \multirow[t]{3}{*}{2} & Pendidikan : & & \\
\hline & a. SLTA ke bawah & & 77,77 \\
\hline & b. Diploma dan S1 & & 22,23 \\
\hline \multirow[t]{4}{*}{3} & Pengalaman usaha (tahun) & 6,42 & \\
\hline & a. $1-5$ tahun & & 66,67 \\
\hline & b. $6-10$ tahun & & 11,11 \\
\hline & c. $10-21$ tahun & & 22,22 \\
\hline \multirow[t]{3}{*}{4} & Kepemilikan ternak & & \\
\hline & a. Jumlah sapi yang dipelihara (ekor) & 4,83 & \\
\hline & b. Jumlah Sapi Laktasi (ekor) & 2,00 & \\
\hline
\end{tabular}

hanya sebanyak $3,23 \%$, sedangkan sisanya (96,77\%) berpendidikan SD dan SLTA (Mandaka dan Hutagaol, 2005). Kemampuan untuk mengadopsi ilmu pengetahuan dipengaruhi oleh tingkat pendidikan peternak. Dengan semakin tingginya tingkat pendidikan peternak, maka cara berfikir peternak akan lebih maju dan terbuka untuk menerima inovasi dalam rangka pengembangan usaha mereka. Keterlibatan mereka dalam usaha peternakan mendukung program pemerintah dalam menciptakan lapangan pekerjaan sendiri dan diharapkan dapat memberi motivasi bagi generasi muda lainnya untuk berusaha.

Pengalaman peternak dalam mengelola usaha sapi perah di Kota Padang Panjang ini 6,42 tahun yang dibagi dalam tiga kelompok pengalaman yaitu, 1-5 tahun (66,67\%), $6-10$ tahun $(11,11 \%)$ 10-21 tahun $(22,22 \%)$. Bila dilihat dari sejarah perkembangan usaha peternakan sapi perah rakyat di Padang Panjang, semestinya banyak peternak yang berpengalaman lebih dari 10 tahun. Namun sebagian dari peternak yang ikut merintis pengembangan sapi perah di daerah ini tidak lagi memelihara sapi perah. Hal ini disebabkan karena sulitnya pemasaran susu sehingga sebagian peternak sapi perah beralih ke usaha budidaya sapi potong dengan mengembangkan jenis sapi simmental. Induk-induk sapi perah yang mereka miliki disilangkan dengan sapi simental melalui inseminasi buatan (IB) dan anaknya dipelihara sebagai sapi potong yang memiliki nilai jual tinggi. Mereka beranggapan bahwa usaha penggemukan sapi potong akan menghasilkan keuntungan yang lebih besar dan cara pemeliharaannya pun tidak terlalu rumit dibandingkan dengan pemeliharaan sapi perah.

Usaha peternakan sapi perah Padang Panjang ini merupakan mata pencaharian utama bagi sebagian $(50,00 \%)$ peternak, sedangkan yang lainnya $(50 \%)$ bermatapencarian utama sebagai petani, PNS, pedagang dan jenis pekerjaan lainnya. Rataan kepemilikan sapi perah 4,83 ekor (3,16 satuan ternak) dengan rataan jumlah sapi laktasi 2,00 ekor atau $41,41 \%$ dari rataan kepemilikan ternak.

Sudono (2003) menyatakan bahwa usaha sapi perah baru akan memberikan keuntungan bila kepemilikan sapi laktasi $60 \%$ dari jumlah sapi yang dipelihara sehingga biaya pemeliharaan dapat ditutupi dengan pendapatan yang diperoleh dari produksi susu dan memberikan keuntungan bagi peternak. Angka kepemilikan sapi perah di Padang Panjang lebih rendah bila dibandingkan dengan rataan kepemilikian sapi perah di Kecamatan Getasan Kabupaten Semarang sebanyak 5,45 ekor dengan rataan sapi laktasi 2,33 ekor (Mukson et al., 2009) namun lebih tinggi bila dibandingkan dengan kepemilikan sapi perah di Desa Tajur Halang Bogor sebanyak4,07 ekor (Krisna,2006). 
Tabel 2. Performa reproduksi sapi perah di Kabupaten 50 Kota dan Kota Padang Panjang

\begin{tabular}{clcc}
\hline No. & \multicolumn{1}{c}{ Variabel } & Kab. 50 Kota & $\begin{array}{c}\text { Kota Padang } \\
\text { Panjang }\end{array}$ \\
\hline 1 & Umur Beranak Pertama (Age at First Calving) (bulan) & $31,63 \pm 6,37$ & $30,17 \pm 4,10$ \\
2 & Masa Kosong (Days Open) (hari) & $260,63 \pm 147,04$ & $192,26 \pm 114,04$ \\
3 & Selang Beranak (Calving Interval) (hari) & $548,63 \pm 168,30$ & $477,26 \pm 114,04$ \\
\hline
\end{tabular}

Di Kabupaten Banyumas 3,27 ekor (Mastuti dan Hidayat, 2009). Rataan produksi susu harian sapi perah di Padang Panjang 9,88 $\mathrm{kg} \pm 2,00 \mathrm{~kg}$.

Hasil penelitian yang dilakukan oleh Mukson, et al. (2009) menunjukkan bahwa secara umum faktor umur, pengalaman usaha, pendidikan, jumlah sapi laktasi, jumlah anggota rumah tangga, curahan tenaga kerja, pakan hijauan, pakan konsentrat dan luas kandang secara bersama-sama berpengaruh sangat nyata terhadap kinerja usaha sapi perah berdasarkan produksi susu. Selanjutnya dijelaskan bahwa secara parsial jumlah ternak laktasi berpengaruh sangat nyata $(\mathrm{P}<0,01)$, umur peternak berpengaruh nyata $(\mathrm{P}<0,05)$, sedangkan pendidikan dan curahan tenaga kerja berpengaruh nyata pada taraf $10 \%$ terhadap kinerja usaha sapi perah.

\section{Umur Beranak Pertama (Age at First Calving)}

Hasil penelitian tentang performa reproduksi sapi perah di Kabupaten 50 Kota dan Kota Padang Panjang dapat dilihat pada Tabel 2. Rataan umur beranak pertama sapi perah di Kabupaten 50 Kota dan Kota Padang Panjang masing-masing $31,63 \pm 6,37$ bulan dan 30,17 \pm 4,10 bulan. Umur beranak pertama ini masih termasuk dalam kategori baik berdasarkan standar Ditjen Peternakan (1992) yaitu antara 2,5-3 tahun, namun berdasarkan hasil penelitian Froidmont et al. (2012) umur beranak pertama yang terbaik yaitu pada umur 22-26 karena akan menghasilkan produksi susu yang maksimal pada laktasi pertama. Umur beranak pertama di Kabupaten 50 Kota dan Kota Padang Panjang lebih lambat dari hasil penelitian Sopiyana (2006) dan Atabany, et al. (2011) yaitu pada umur 29,13 bulan dan 28,7 bulan. Hasil uji t menunjukkan bahwa tidak ada perbedaan $(\mathrm{P}>0,05)$ umur beranak pertama sapi perah di kedua daerah penelitian.

Hal ini disebabkan karena sistim perolehan bibit sapi perahnya hampir sama dimana peternak menerima sapi dalam keadaan bunting 4-5 bulan. Bibit sapi perah yang dipelihara oleh PT. Situjuh Organik Madani di Kabupaten 50 Kota diperoleh dengan cara membeli langsung ke daerah Jawa Barat melalui agen di daerah tersebut, sedangkan peternak di Kota Padang Panjang memperolah sapi melalui Dinas Peternakan karena umumnya sapi yang mereka pelihara adalah sapi bantuan pemerintah. Bibit sapi yang telah bunting 4-5 bulan akan melahirkan setelah beberapa bulan dipelihara oleh peternak. Namun ada beberapa ekor sapi yang mengalami keguguran akibat perjalanan jauh dari daerah asalnya sehingga peternak harus mengawinkannya kembali dengan cara inseminasi buatan (IB) di farm mereka masing-masing. Hal ini akan memperpanjang umur beranak pertama yang tentunya juga akan menambah biaya pemeliharaan. Faktor lain yang dapat menjadi penyebab lamanya umur beranak pertama adalah keterlambatan peternak pemilik di daerah asalnya untuk mengawinkan sapi dara disebabkan kondisi tubuh sapi yang kecil atau lambatnya dewasa kelamin.

Keputusan tentang kapan seekor sapi mulai dikawinkan biasanya didasarkan terutama pada usia dan kondisi tubuh sapi yang juga dipengaruhi oleh tingkat nutrisi ransum dan kesehatan sapi. Pertumbuhan yang buruk selama periode pemeliharaan disebabkan nutrisi yang rendah dan atau penyakit akan menyebabkan pertumbuhannya terganggu dan tertundanya dewasa kelamin (Tozer dan Heinrichs, 2001; Brickell et al., 2009). Sudono (2003) menyatakan bahwa sapi yang mendapat nutrisi yang baik setelah sapih dapat mencapai dewasa kelamin pada umur 9-11 
bulan sehingga dapat beranak pada umur 2 tahun, sedangkan sapi yang mendapat nutrisi yang buruk baru akan dewasa kelamin pada umur 18-20 bulan. Asupan protein dan energi merupakan faktor yang paling mempengaruhi kondisi tubuh sapi, ketersediaan energi yang tidak memadai dalam ransum akan menunda dewasa kelamin pada sapi dara (Graves dan McLean, 2003). Jika sapi dara yang baru memulai siklus reproduksi normal mendapat ransum yang defisiensi energi, akan menyebabkan siklus reproduksinya terhenti (Lanyasunya et al., 2005).

Menurut Tozer dan Heinrichs (2001) mempercepat umur beranak pertama akan mengurangi biaya pemeliharaan sapi dara. Beranak pertama pada umur $<24$ bulan akan memberikan keuntungan ekonomi dengan dampak minimal pada kemampuan laktasi selama sapi diberi makan dengan baik sebelum pubertas dan mencapai bobot badan yang memadai pada saat melahirkan (Amburgh, et $a l .$, 1998). Dari hasil penelitian yang dilakukan Tozer dan Henirichs (2001), biaya pemeliharaan akan berkurang $18 \%$ jika umur sapi beranak pertama dipercepat dari 25 bulan menjadi 21 bulan. Namun hasil penelitian Hoffman et al. (1996) mempercepat umur beranak pertama dibawah umur 23 bulan umumnya menyebabkan menurunnya produksi susu selama laktasi pertama, sedangkan menunda waktu beranak pertama sampai 26,5 bulan meningkatkan produksi susu pada laktasi pertama sebanyak $275 \mathrm{~kg}$ dibandingkan dengan sapi yang beranak pertama pada umur 23,3 bulan.

\section{Masa Kosong (Days Open)}

Masa kosong sapi perah di Kabupaten 50 Kota dan Kota Padang Panjang seperti yang terlihat pada Tabel 2. masing-masing $260,79 \pm 146,90$ dan $192,26 \pm 114,04$. Masa kosong ini jauh lebih panjang dari hasil penelitian Leksnawati (2009) dan Atabany, et al. (2011) pada sapi perah di Boyolali dan Purwokerto yaitu masing-masing 103 $\pm 19,92$ hari dan 138,8 $\pm 7,9$ hari. Dela Rosa (2002) menyatakan bahwa selang beranak 12-13 bulan dapat terlaksana bila masa kosong berkisar antara 85-115 hari. Masa kosong yang terlalu pendek kurang dari 85 hari akan memperpendek panjang laktasi yang berakibat kepada berkurangnya jumlah produksi susu pada laktasi yang sedang berjalan (Kusnadi dan Juarni 2007). Bertambahnya masa kosong di atas 165 hari akan meningkatkan produksi susu (Atabany et al., 2011). Panjangnya masa kosong pada sapi perah di Kabupaten 50 Kota dan Kota Padang Panjang antara lain disebabkan karena : 1) lamanya muncul berahi kembali setelah melahirkan; 2) kurangnya pengetahuan peternak dalam mendeteksi estrus setelah melahirkan; dan 3) terjadinya kawin berulang. Menurut Stevensen (2001) penyebab panjangnya masa kosong terjadi karena gangguan fisiologis (reproduksi), keterlambatan IB, berahi tenang sehingga sulit mendeteksinya dan teknik IB yang kurang baik. Peternak di Kabupaten 50 Kota maupun di Kota Padang Panjang mengeluhkan sering terjadinya kegagalan IB sehingga service per conception menjadi tinggi. Panjangnya masa kosong ini akan berakibat kepada panjangnya selang beranak. Petugas kesehatan hewan setempat mengatakan bahwa seringnya terjadi kegagalan IB karena : 1) hipofungsi ovarium yang ditunjukkan dengan permukaan ovarium yang licin karena tidak adanya pertumbuhan folikel yang menyebabkan tidak munculnya gejala berahi (anestrus) setelah melahirkan; 2) kurang lancarnya komunikasi antara peternak dengan inseminator sehingga waktu inseminasi tidak tepat. Ketidaksuburan ternak adalah salah satu faktor penyebab kerugian dalam usaha peternakan sapi perah. Lanyasunya, et al. (2005) menyatakan bahwa efisiensi reproduksi yang tinggi pada suatu usaha ternak sapi perah tergantung kepada nutrisi dan manajemen yang baik. Dalam penelitiannya dijelaskan bahwa selain defisiensi energi dan protein, defisiensi mineral juga sangat terkait dalam menurunkan performans reproduksi sapi perah. Hardjopranjoto (1995) menguraikan bahwa kejadian kawin berulang pada sapi perah sering terjadi pada perkawinan dengan inseminasi buatan dibandingkan perkawinan alam, dan hal ini lebih sering terjadi pada induk yang telah beberapa kali melahirkan yang disebabkan karena kondisi 
lingkungan uterus pada sapi yang tua semakin kurang serasi untuk kehidupan embrio.

Menurut Royal et al. (2000) kegagalan kebuntingan dapat menggambarkan adanya disfungsi hypotalamus, kelenjar pituitary, ovarium, uterus maupun kematian embrio dini. Pada induk normal sering menjadi penyebab kawin berulang karena pada dasarnya embrio sampai umur 40 hari kondisinya masih labil dan mudah dipengaruhi oleh lingkungan yang tidak serasi atau kekurangan pakan.

Hasil uji $t$ memperlihatkan bahwa tidak ada perbedaan $(\mathrm{P}>0,05)$ masa kosong antara sapi perah di Kabupaten 50 Kota dan Kota Padang Panjang. Hal ini disebabkan karena permasalahan yang dihadapi oleh kedua usaha peternakan ini hampir sama yaitu 1) tingginya angka service per conception; dan 2) kualitas makanan yang rendah sehingga kemungkinan adanya gangguan reproduksi karena kekurangan nutrisi.

\section{Selang Beranak (Calving Interval)}

Selang beranak sapi perah di Kabupaten 50 Kota dan Kota Padang Panjang masing-

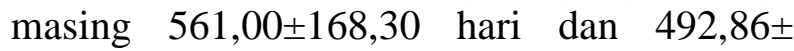
128,38 hari. Selang beranak merupakan salah satu yang menjadi faktor dalam penilaian penampilan reproduksi. Selang beranak di Kabupaten 50 Kota dan Kota Padang Panjang tidak termasuk dalam rentang yang ideal karena menurut Sudono (2003) selang beranak yang optimal adalah 12-13 bulan. Selang beranak sapi perah di kedua daerah ini lebih lama bila dibandingkan dengan hasil penelitian Iskandar dan Farizal (2011), dan Sopiyana (2006) dengan rataan selang beranak sapi perah di daerah penelitiannya berturut-turut 377 hari dan 376,03 hari. Rendahnya tingkat pertambahan populasi sapi perah di Indonesia sebagai akibat menurunnya tingkat kelahiran yang disebabkan oleh selang beranak yang melebihi 12 bulan (Siregar, 2003). Ball dan Peters (2004) menyatakan bahwa efisiensi Reproduksi dikatakan baik apabila seekor induk sapi dapat menghasilkan satu pedet dalam satu tahun. Semakin lama selang beranak maka biaya pemeliharaan yang dikeluarkan oleh peternak semakin tinggi dan kesempatan untuk mendapatkan kentungan dari pedet yang dilahirkan dan produksi susu semakin tertunda. Dengan selang beranak 12-13 bulan, peternak akan mendapatkan keuntungan yang optimal. Disamping itu tingkat kelahiran dan pertambahan populasi sapi perah secara nasional dapat ditingkatkan.

Selang beranak yang panjang dapat disebabkan oleh panjangnya masa kosong. Lamanya kebuntingan juga akan menentukan panjangnya selang beranak (Nurjadi dan Wahjuningsih, 2011). Panjangnya selang beranak sapi perah di Kabupaten 50 Kota dan Kota Padang Panjang ini disebabkan karena lamanya waktu kosong seperti terlihat di atas bahwa masa kosong sapi perah di kedua daerah ini cukup panjang yaitu $260,79 \pm 146,90$ dan 192,26 $\pm 114,04$. Tidak ada perbedaan antara selang beranak sapi perah di Kabupaten 50 Kota dan Kota Padang Panjang ( $P>0,05)$. Hal ini disebabkan karena tatalaksana pemeliharaan sapi perah di kedua daerah ini tidak jauh berbeda dalam pemilihan bibit, manajemen pakan dan manajemen reproduksi. Disamping itu masa kosong sapi perah di kedua daerah ini secara statistik tidak berbeda sehingga selang beranak pun tidak berbeda.

\section{KESIMPULAN}

Hasil penelitian menunjukkah bahwa performa reproduksi sapi perah di Kabupaten 50 Kota dan Kota Padang Panjang yang terdiri dari umur beranak pertama (Age of First Calving), masa kosong (Days Open) dan selang beranak (Calving Interval) secara statistik tidak menunjukkan adanya perbedaan $(\mathrm{P}>0,05)$. Rataan umur beranak pertama, masa kosong dan selang beranak sapi perah di Kabupaten 50 Kota berturut-turut adalah $31,63 \pm 6,37$ bulan, 260,63 $\pm 147,04$ hari dan 548,63 $\pm 168,3$ hari, sedangkan di Kota Padang Panjang berturut-turut $30,17 \pm 4,10$ bulan, 192,26 \pm 114,04 hari dan $477,26 \pm 114,04$ hari. Performa reproduksi ini belum baik karena melebihi waktu yang optimal untuk ketiga variabel tersebut. Dalam upaya pengembangan dan peningkatan populasi sapi perah di Sumatera Barat permasalahan ini perlu diatasi dengan pembenahan tatalaksana pemeliharaan 
sehingga performans reproduksi sapi perah menjadi optimal.

\section{DAFTAR PUSTAKA}

Amburgh, V. M. E., D. M. Galton, D. E. Bauman, R. W Everett, D. G. Fox, L. E. Chase, and H. N. Erb. 1998. Effects of three prepubertal body growth rates on performance of Holsteinheifersduring first lactation. J. Dairy Sci. 81:527-538.

Atabany, A., B.P. Purwanto, T.Toharmat, dan A. Anggraeni. 2011. Hubungan masa kosong dengan produktivitas pada sapi perah friesian holstein di Baturraden, Indonesia. Media Peternakan-Journal of Animal Science and Technology 34(2):77-82.

Badan Pusat Statistik Kabupaten Lima Puluh Kota. 2011. Kabupaten Lima Puluh Kota dalam Angka. Badan Pusat Statistik Kabupaten Lima Puluh Kota.

Badan Pusat Statistik Kota Padang Panjang. 2011. Padang Panjang dalam Angka. Badan Pusat Statistik Kota Padang Panjang.

Ball, P. J., and A.R. Peters. 2004. Reproduction in Cattle. Blackwell Publishing. Australia.

Brickell, J.S., N. Bourne, M.M. McGowan, and D.C. Wathes. 2009. Effect of growth and development during the rearing period on the subsequent fertility of nulliparous Holstein-Friesian heifers. Theriogenology 72:408-416. doi:10. 1016/j.theriogenology.2009.03.015

Bujko, J., J. Candrák, P. Strapák, J. Žitný, \& C. Hrnčár. 2012. Evaluation of relationship between traits of milk production and reproduction traits in dairy cows of the Slovak spotted breed. Scientific Papers Animal Science and Biotechnologies 45(1):115-120.

De la Rosa, R.R.M.A., G.F. Osnaya and G.R. Perez. 2002. Integral analysis of the days opened up in the reproductive efficiency of cluster milkman. XXVI
National Congress of Buiatria of the Mexican Assosiation of Doctor Specialist Veterinarians in Bovine. Acapulco, Mexico.

Dinas Peternakan Propinsi Sumatera Barat. 2012. Data base peternakan propinsi sumatera barat tahun 1996 s/d 2005. dinas peternakan Provinsi Sumbar. Padang.

Direktorat Jenderal Peternakan dan Kesehatan Hewan. 2013. Data 5 tahun subsektor peternakan ditjen peternakan dan kesehatan hewan kementerian pertanian republik indonesia, Jakarta.

Ditjen Peternakan. 1992. Pedoman identifikasi faktor penentu teknis peternakan. Proyek Peningkatan Produksi Peternakan. Diklat Peternakan, Jakarta.

Froidmont, E., P. Mayeres, P. Picron, A. Turlot, V. Planchon, \& D. Stilmant. 2012. Association between age at first calving, year and season of first calving and milk production in Holstein cows. Animal 7(04): 665-672.

Graves, W.M. and A.K. McLean. 2003. Improving dairy heifer reproduction management cooperative extension service. University of Gerogia College of Agriculture and Environemtal Science. Bulletin 1235/July 2003 1-4.

Hardjopranjoto, S. 1995. Ilmu Kemajiran pada Ternak. Airlangga University Press, Surabaya.

Heinrichs, A.J., 1993. Raising Dairy Replacement to meet the needs of the $21^{\text {st }}$ century. J. Dairy Sci. 76:1254-1260.

Hoffman, P.C., N.M. Brehm, S.G. Price, and A. Prill-Adema. 1996. Effect of ccelerated growth and early calving on lactation performance of primiparous Holstein heifer. J. Dairy Sci. 79:20242031.

Iskandar dan Farizal. 2011. Prestasi reproduksi sapi persilangan yang dipelihara di dataran rendah dan dataran tinggi Jambi. 
Jurnal Penelitian Universitas Jambi Seri Sains 13(1):25-28.

Krisna, R. dan E. Manshur. 2006. Tingkat kepemilikan sapi (skala usaha)peternakan dan hubungannya dengan keuntungan usaha tani ternak pada kelompok tani ternak sapi perah di desa Tajur Halang Bogor. Jurnal Penyuluhan Pertanian Vol.1 No.1, Mei 2006.

Kusnadi, U dan, E Juarni. 2007. Optimalisasi pendapatan usaha pemeliharaan sapi perah dalam upaya peningkatan produksi susu nasional. Wartazoa Vol 17 No. 2 Tahun 2007. Balai Penelitian Ternak. Bogor.

Lanyasunya, T. P., H.H. Musa, Z.P. Yang, D.M. Mekki, \& E.A. Mukisira. 2005. Effects of poor nutrition on reproduction of dairy stock on smallholder farms in the tropics. Pakistan Journal of Nutrition 4(2):117-122

Leksnawati, A.Y. 2009. Penampilan reproduksi induk sapi perah peranakan Friesian Holstein di Kelompok Ternak KUD Mojosongo Boyolali. Digital Library Perpustakaan Digital Universitas Sebelas Maret. http://digilib.uns.ac.id labstrak 11463 penampilan-reproduksiinduk-sapi-perah-peranakan-friesianholstein-di-kelompok-ternak-kudmojosongo-boyolali.html.

Mandaka, S., dan M. P. Hutagaol. 2005. Analisis fungsi keuntungan, efisiensi ekonomi dan kemungkinan skema kredit bagi pengembangan skala usaha peternakan sapi perah rakyat di Keluraharan Kebon Pedes, Kota Bogor. Jurnal Agro Ekonomi 23(2):191-208.

Mastuti, S., dan N.N. Hidayat. 2009. Peranan tenaga kerja perempuan dalam usaha ternak sapi perah di Kabupaten Banyumas. Animal Prod. 11:40-47.

Mukson, T. Ekowati, M. Handayani dan D.W. Harjanti. 2009. Faktor-faktor yang mempengaruhi kinerja usaha ternak sapi perah rakyat di Kecamatan Getasan Kabupaten Semarang. Prosiding Seminar Nasional Kebangkitan Peternakan. Semarang.

Nurjadi dan S.Wahyuningsih. 2011. Penampilan reproduksi sapi peranakan ongole dan peranakan limousin di Kabupaten Malang. Jurnak Ternak Tropika 12(1) :76-81.

Pirlo, G., F. Miglior and M. Speroni. 2000 Effect of age at first calving on production traits and on difference be-tween milk returns and rearing costs in Italian Holsteins. Journal of Dairy Science 83:606-608.

Royal, M.D., A.O. Darwash, A.P.F. Flint, R. Webb, J.A. Woolliams and G.E. Lammbing. 2000. Declining fertility in dairy cattle : changes in traditional and endocrine parameters of fertility. Anim. Sci. 70:487-501.

Siregar, S. B. 2003. Peluang dan tantangan peningkatan produksi susu nasional. Wartazoa 13(2):48-55.

Sopiyana, S. 2006. Analisis penerapan aspek teknis peternakan pada berbagai skala usaha peternakan sapi perah di Kabupaten Garut Jawa Barat. Animal Production Vol.8 (3):216-225.

Stevensen, J.S. 2001. Reproductive management of dairy cows in high milk producing herds. J. Dairy Sci. 84 (E.Suppl.): E128-E143.

Sudono, A., Rosdiana, R. Fina dan B. Setiawan. 2003. Beternak Sapi perah Secara Intensif. Penerbit Agro Media Pustaka. Jakarta.

Tozer, P. R., and A. J. Heinrichs. 2001. What affects the costs of raising replacement dairy heifers: A multiple-component analysis. J. Dairy Sci. 84:1836-1844. 